\title{
MODERNIZATION OF RAILWAY STATIONS ČESKÁ LÍPA AND KARLOVY VARY WITH THE EXPECTED CO-FINANCING FROM EUROPEAN FUNDS FORM OPD2
}

\author{
RADEK KratochVíL*, MaRIa JaneŠOvÁ, JiŘí VoPAVA \\ CTU in Prague, Czech Technical University in Prague - Faculty of Transportation Sciences, Konviktská 20, 110 \\ 00, Prague 1, Czech Republic \\ * corresponding author: kratochvil.radek@seznam.cz
}

Abstract.

The article describes the planned modernization of railway stations in Česká Lípa and Karlovy Vary, their scope and financing. The emphasis is laid on the expected co-financing of these projects from European structural and investment funds planned for the years 2016-2020. It is case of the operational program Transport - OPD2. The study compares the two projects from many aspects, in particular from the economic and structural-urban planning points of view.

KEYWORDS: modernization, railway station, OPD2, construction costs.

\section{European Structural and INVESTMENT FUNDS - OPD2}

On 12 May, 2015 The European Commission approved Operační program Doprava pro období 2014-2020 - the newly designated as OPD2. In the past, the Transport Operational Program designed for the years 2007 - 2013 was used the Czech Republic. This OPD2 program will provide the Czech Republic with the possibility to draw from the EU funds the amount of almost EUR 4.7 billion, in particular for the development of road and rail infrastructure.

General allocation of OPD2: 5524434 631EUR, including the European share: 695769 435EUR

\section{Programming Document OPD2} (2014CZ16M1OP001) contains detailed information about co-financing projects in various areas of transportation. We will within this article deal with the issue of rail transport. Here, there are some important and interesting facts contained in this document relating to the modernization of rail and multimodal transport: Currently approximately 9,500 km of railway tracks are operated in the Czech Republic, which makes it - considering the total area of the Czech Republic - one of the densest rail networks in the world. The big problem of the railway network in the Czech Republic is its low technical level (insufficient track speed and frequent speed drops, low capacity, lack of interoperability, insufficient parameters for freight transportation, particularly the length of tracks in stations and terminals for multimodal transport), poor condition and lack of amenities of transport terminals, railway stations and stops and the related low comfort for passengers, resulting in low competitiveness in comparison with the road transport in most important directions and aspects. Co-financing of the rail transport within OPD2 is possible under the Priority Axis 1, where inter alia, the following objectives are determined:

- Point 1.1 Improving the infrastructure for increased competitiveness and greater use of rail transport

For this priority axis is the support of the EU is set in the amount of EUR 2,395,964,680. The share of overall EU support in the Operational Program is $51.02 \%$ - it is clear from Table 2 (Overview of investment strategy of the Operational Program) [1]

\section{Modernization of the Railway Station In Česká Lípa}

The Main Railway Station Česká Lípa [2] is located in the Liberec region. The railway station is located in the south-western part of the town of Česká Lípa. This is the crossroads of four railway lines, see the specification below. The railway junction Česká Lípa is the second largest rail hub in the Liberec region (just behind Liberec).

\section{Specifications:}

IDS: IDOL (Liberec)

List of numbers of tracks: 080, 081, 086, 087 [2]

GPS of the railway station:

N $50^{\circ} 40^{\prime} 31,302$; E $14^{\circ} 31^{\prime} 59,46$

The railway station should undergo a complete modernization. The Railway Infrastructure Administration [3], hereinafter referred to as SŽDC (as the main investor) and Skanska a.s. (as the contractor / builder) have officially concluded the contract for this modernization. Funds will be provided by the State Fund for Transport Infrastructure and the construction is designed for co-financing from the European structural and investment funds - 




Figure 1. Modernization of the Česká Lípa railway station - The architectural design of the construction project (14-334-201) 5]

Operational Program Transport - OPD2. At this railway station in Česká Lípa a new terminal building will be built for passengers and at the same time the existing station building is to be reconstructed so that it can accommodate the new safety equipment technology. A new underpass subway and three new platforms with steel roofing and elevators will be built at the station. Furthermore, two bridges are to be remodelled and several other alterations shall be made within this construction project.

\section{Basic information on the construction project:} Name: Modernizace žst. Česká Lípa

Investor: Správa železniční dopravní cesty, státní organizace (SŽDC)

Contractor/Builder: Skanska a.s. [4]

Designer: SUDOP PRAHA a.s.

Construction Period: November 2015 - May 2017

Construction costs: 1006416679 CZK not including VAT

According to the statement of $\mathrm{S} \AA_{j} \mathrm{DC}$ the $\mathrm{EU}$ usually contribute up to $80 \%$ of the total eligible costs.

The project documentation prepared by SUDOP PRAHA a.s. indicates that the construction project of the modernization of the Česká Lípa railway station will fundamentally affect the transport in the whole Česká Lípa county. In addition to rebuilding the railway station the project also involves the revitalization of some connecting sections, on which the speed of trains will be increased consequently. The aim of the changes is a new configuration of the track so that it can accommodate multilevel platforms, increasing the speed from $40-60$ to $65-100 \mathrm{~km} / \mathrm{h}$ on most tracks for passenger trains and elimination of non-essential parts of the track. The railway station of Česká Lípa has been negatively affected by the division into two disjointed parts. As a result of this the station is confusing for passengers, too large and not very comfortable for a train change. The construction adjustments will unite the two parts of the railway

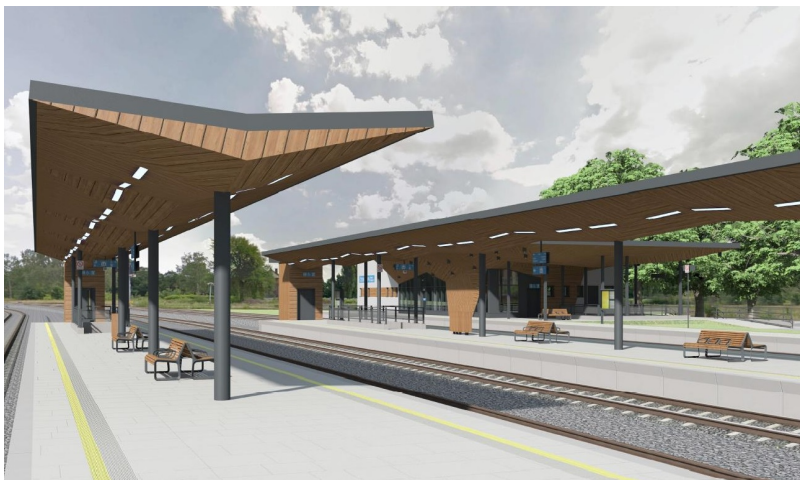

FiguRE 2. Modernization of the Česká Lípa railway station - The architectural design of the construction project (14-334-201) [5]

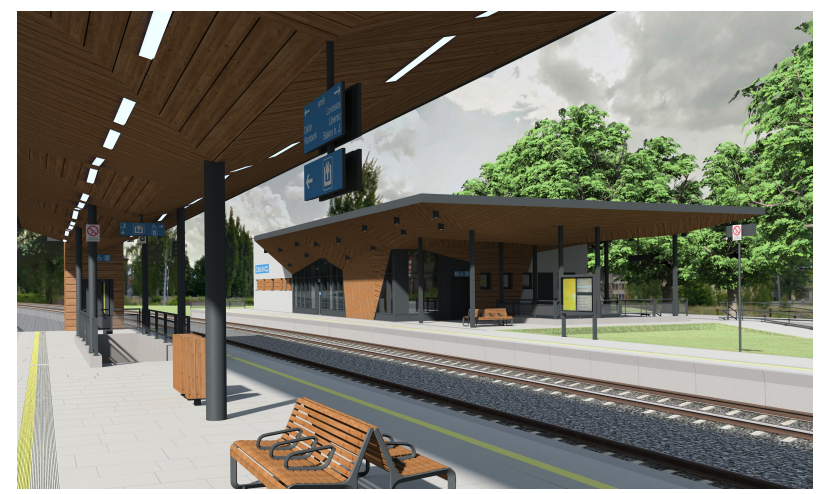

FiguRE 3. Modernization of the Česká Lípa railway station - The architectural design of the construction project (14-334-201) [5]

station and the passenger area will move closer to the town center by about $250 \mathrm{~m}$.

\section{Modernization of the Railway STATION IN KARLOVY VARY}

The Railway Station of Karlovy Vary 2] is located in the Karlovy Vary region. The railway station (unofficially called the "Upper Station") is a transport hub of the city Karlovy Varyboth for the passenger and freight rail transport. The station is located on a major route Cheb - Chomutov, track 140.

\section{Specifications:}

IDS: DUK (Ústí nad Labem), IDOK (Karlovy Vary) List of numbers of tracks: 140, 141, 142 [2] GPS of the railway station:

$\mathrm{N} 50^{\circ} 14^{\prime} 7,737$; E $12^{\circ} 52^{\prime}, 647$

The railway station should undergo a complete modernization. SŽDC (as the main investor) and Skanska (as the contractor/builder) have agreed on this modernization. The construction project has been designed to be co-financed from the European structural and investment funds - Operational Program Transport - OPD2. The new railway station with optimum passenger handling capacity will be 


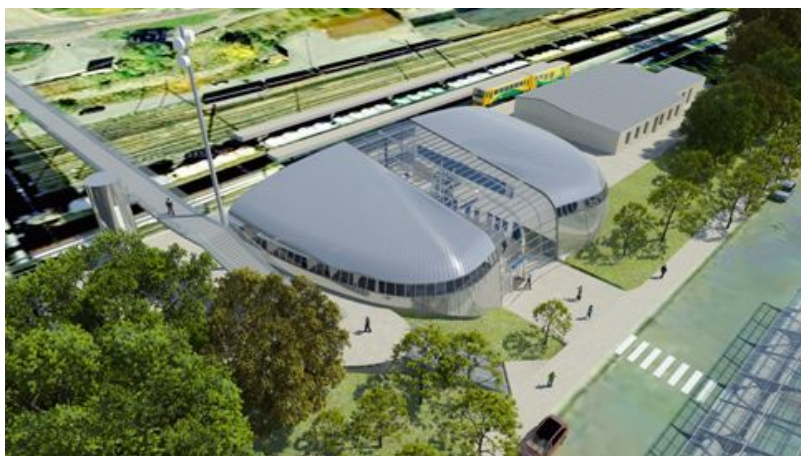

Figure 4. Visualization of the railway station of Karlovy Vary, the Project by SUDOP PRAHA a.s. 5

built by Skanska a.s. without interrupting the train service. To ensure the functionality of the station the eastern part of the existing building will be retained, which will perform the basic functions of the railway station during the construction period. After the construction project completion also this eastern part of the station building will be demolished. Consequently, platform adjustments will be implemented. The new building will have one above ground and one underground floor. It will be dominated by the hall with a glass roof, which passes through both floors and divides the building into two halves.

Basic information on the construction project: Name: Modernizace žst. Karlovy Vary

Investor: Správa železniční dopravní cesty, státní organizace (SŽDC)

Contractor/Builder: Skanska a.s., division Pozemní stavitelství západ [4]

Designer: SUDOP PRAHA a.s.

Construction Beginning: 22.4.2015

Construction costs: $75800000 \mathrm{CZK}$ not including VAT

\section{Conclusion}

This article has compared two different projects on modernization of railway stations. The two projects vary greatly in terms of their scope of works and, of course, in terms of the related budgets. The planned modernization of the railway station of Česká Lípa is much broader and includes, for example reconstruction

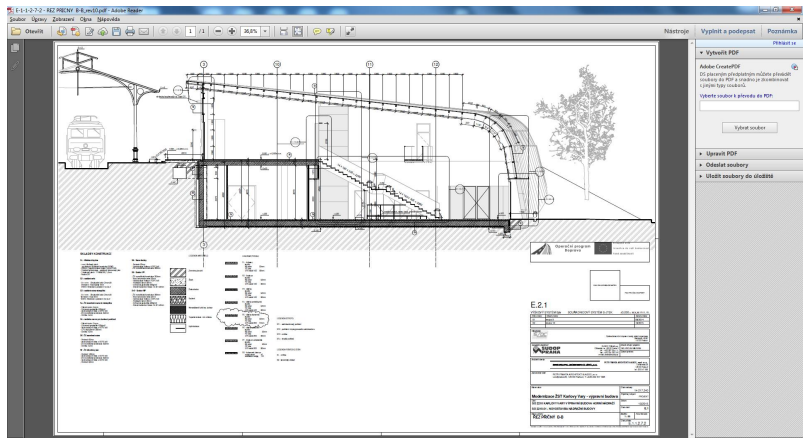

FiguRE 5. The modernization of the railway station of Karlovy Vary - station building, a cross-section B-B, Project (14-217.240) 5]

\begin{tabular}{||l|l||}
\hline Žel. st. Česká Lípa & 1006,4 \\
\hline Žel. st. Karlovy Vary & 75,8 \\
\hline
\end{tabular}

TABLE 1. Construction costs of projects (CZK million excluding VAT)

of two bridges, construction of 19 railway crossings and 32 switches on the $33 \mathrm{~km}$ long track.

Both construction projects have the same investors, designers and construction contractors and both have been designed to be co-financed from European structural and investment funds - Operational Program Transport - OPD2. This is a very important parameter of the project, because it would be very difficult to finance the projects of this size without the EU support.

\section{REFERENCES}

[1] Portál SŽDC [online]. Evropské strukturální a investiční fondy, operační program doprava. [2016-02-10], http://www.opd.cz

[2] Portál ČD [online]. České dráhy a.s. Informace o nádražích. [2016-02-10], http://www.cd.cz/cd-online/stanice.php.

[3] Portál OPD [online]. Správa železniční dopravní cesty, s.o. Spolufinancování z EU. [2016-02-10], http://www.szdc.cz/modernizace-drahy/ spolufinancovani-z-eu/op-doprava.html

[4] Portál společnosti Skanska a.s. [online]. Skanska. [2016-02-10], http://www.skanska.cz.

[5] Portál SUDOP PRAHA [online]. SUDOP PRAHA a.s. [2016-02-10], http://www. sudop.cz. 